\title{
DISASTER CAUSATIVE AGENTS: AN EXAMINATION OF THE SOCIAL AND POLITICAL CONTEXT IN THE NIGER DELTA REGION
}

\author{
MATHEW OCHOLI \\ Royal Roads University, Victoria, Canada
}

\begin{abstract}
Disasters as phenomena, to a greater extent, are created whether they are natural or technological. There are causative agents that are implicated in every disaster. Disasters are incubated by these agents acting independently or collectively. The agents could be social, political, environmental or underdevelopment factors. How the agents act individually and collectively to create disaster depends on the context within which they occur. The Niger Delta region has experienced multiple disasters over a prolonged period of time. These disasters range from oil spills that led to community responses of various dimensions to the more recent militancy by agitated community members which created a different type of disaster, leading to loss of lives and wanton destruction of properties. This paper will show that the disasters have been largely influenced by social and political elements at play in the Niger Delta region. How the elements contributed in creating the disasters within the context of the Niger Delta region is the focus of this paper. This paper analyzes the social and political dynamics in the Niger Delta region, and explain how they have acted individually and collectively to influence the disasters in the region. It also identifies who the key actors are and what their roles are in creating the disasters. The events and happenings in the Niger Delta region are documented in academic papers, news articles and other reports. This paper examines these sources to determine the social and political elements that were at play within the Niger Delta region from the 1950s, when oil operations began, to the present day. It concludes with recommendations on how to mitigate such situations in future.
\end{abstract}

Keywords: community, conflict, crisis, disaster, environmental, Niger Delta, oil spills, political, social, vulnerability.

\section{INTRODUCTION}

Niger Delta Region, the focus of this paper, is located in the South of Nigeria. According to the Niger Delta Human Development Report [1], it occupies 7.5\% of the total land area of Nigeria, $70,000 \mathrm{~km}^{2}$, and is home to approximately 30 million people. The region holds $90 \%$ of Nigeria's oil and gas deposit, contributing about $97 \%$ of the nation's foreign exchange revenue. As it is currently, Nigeria can be said to be operating a mono-economy that is heavily dependent on oil and gas revenue. Oil accounts for about $79.5 \%$ of total government revenue.

The Niger Delta Region has a background history that has contributed to the social, developmental and political paradox of the region. These have given rise to multiple disasters with impact on livelihood of the people as is discussed in this paper. Disasters as phenomena, to a greater extent, are created whether they are natural or technological. There are causative agents that are implicated in every disaster. Disasters are incubated by these agents acting independently or collectively. The agents could be social, political, environmental or underdevelopment factors. How the agents act individually and collectively to create disaster depends on the context within which they occur. The Niger Delta Region has experienced several events over the last six decades. These events, like oil spills, have led to community responses of various dimensions and the more recent militancy by agitated community members which created a different type of complex situation leading to loss of lives and wanton destruction of properties. 
Researchers have assessed and evaluated these events from different perspectives, but very little focus has been on assessing them from the point of view of disasters. As a result, recommendations made have not been from the understanding of the complexity and multi-dimensionality of disasters as social and cultural events that are created.

This paper discusses some disasters in the Niger Delta area and examines the causative agents at play and how they have acted together to create the disasters.

\section{SOCIAL, DEVELOPMENTAL AND POLITICAL CONTEXT IN THE NIGER DELTA}

The expectation is that a region like the Niger Delta that harbours a greater part of Nigeria's income revenue will be the best-off being in the midst of what one could term "affluence" or "wealth". The reality on ground however, is that the region is the worst off. Disillusionment and frustration has been the bane of the people in this region. The people have witnessed deprivation in all aspects of their lives. As the Niger Delta Human Development Report [1] referred to the situation:

"They have seen one government-sponsored development agency after another, without any significant changes. Instead, their physical environment has been deteriorating at an alarming rate, which hinders economic prospects and harms human well-being. There have been long years of neglect."

\subsection{Social context}

Socially, the people of the Niger Delta have been hugely impacted by the change in their environment which has influenced their socio-cultural wellbeing. The environment, that was once described as serene, has now become chaotic and lawless. It is like an invasion which they were not prepared for. Such wanton attacks on a people's culture and social organization upturns their social and economic environment and creates vulnerabilities that they (the communities) are not prepared or equipped for. For example, the youths who should be at the bottom of leadership ladder in communities have suddenly taken charge in the region and can no longer be controlled by their traditional leadership structures, which as it is now, in most communities in the region, exist only in name but are no longer effective [1].

The people of Niger Delta depend solely on their environment for their source of livelihood. "they are predominantly farmers, fishermen and hunters" [2]. The destruction of their traditional livelihood sources, for example pollution of water bodies by oil and contamination of land for farming, meant a big migration of people from the rural areas to seek for other sources of revenue. The Niger Delta Human Development Report [1] reports that traditional economic pursuit will suffer as a long as easy money flows from the oil companies." There is no doubt "Oil companies have played a significant and dominant role in shaping and reshaping the landscape, economy, politics and socio-cultural life of the oil communities" in the Niger Delta [2]. Another social concern in the Niger Delta Region is the influx of migrants which destabilizes the social order in the region. Migrants in fluxing (in search of oil wealth) into the region replace the people who have left. Not being from this region, their concern is more about making gains. They are not concerned with the wellbeing of the communities, resource conservation or the protection of the environment [1]. Furthermore, the migrant issues have worsened congestion in rural and urban areas leading to "problems such as poor housing conditions; low levels of personal hygiene and environmental sanitation; the dumping of solid waste in streets; gutters and river channels; and poor health facilities." These situations did not only affect the urban cities but have also 
permeated the rural environment disrupting the orderliness that has once been the pride of the rural communities. Local cultures and community level safeguards in the rural communities have been diluted leaving the communities more vulnerable and open to hazards. In short, the socio-cultural, political and economic lives of the people of the region have been shattered and totally destabilized.

Incessant air pollution due to indiscriminate flaring of gas has resulted in increased medical cost and this indirectly increases the poverty status of the people.

\subsection{Environmental and political context}

Afinotan and Ojakorotu [3] report that prior to the advent of oil exploration in the Niger Delta Region in 1956, "the region was essentially a pristine environment which supported substantial subsistence resources for the mostly sedentary population". Environmental management which was practiced right from the colonial era in the region, is now a relic of what used to be in place [1]. Unfortunately, poor environmental regulation, not just in the region alone, but in the whole country has indirectly contributed to the environmental degradation that raped the environment in Niger Delta Region. All efforts at regulation or even just understanding the state of affairs of the environment in the region have not been successful. UNDP reports that a comprehensive environmental survey carried out by Niger Delta Environmental Survey in 1997, was never published.

Several activities have contributed to the environmental degradation in the region, the worst culprit is degradation caused to the environment by several decades of oil production. For example, oil exploration and drilling operation activities in the Niger Delta Region has caused destruction on human settlements, farmlands, vegetation, polluted underground water and destroyed fish, fauna, and polluted fishing grounds with toxic waste materials [3]. The case of Ogoniland is a very important example of the environmental degradation and destruction of the environment from oil spill. The United Nations Environmental Plan [4] produced a report about the oil pollution in Ogoniland. According to the report, the community has experienced recurring oil spills from 1958, when oil operation started, to 2016, about 58 years. The history of pollution in Ogoniland, from the basis of the oil spill, has been described as tragic because it has put the people of the land at odds with government and industry, leading to lack of trust between the parties. The Ogoni community is at the receiving end of the confusion and stalemate that has ensued as a result of the issues related to oil spill in Ogoniland.

All efforts to reconcile the communities with the oil industry, which in this case is Shell Petroleum Development Company (SPDC), Nigeria Ltd, by the Government at the national level has not yielded positive result. As a result of the politics, lack of trust and suspicions, Ogoniland continues to live in neglect, underdevelopment and abject poverty, that seems to have been further complicated by the degradation of the environment by oil spills. There are serious threats to community livelihood sources, threats to human health from contaminated drinking water, and "concerns over the viability and productivity of ecosystems" [4]. The people of Ogoniland tried to respond in their own way, but rather than mitigate the situation, it has deepened the confusion and increased the pollution issues. The report concluded that it will take between 25 to 30 years to totally clean up Ogoniland. This is a herculean, if not impossible task, considering that in all these years that the environment has been gradually destroyed, nothing was done to remedy the situation. Let's assume the clean up of the land is achieved, there is still left the socio-cultural structures/systems of the people that have been destroyed and new vulnerabilities that have been created. The question is how can these be cleaned up or restored. 
Afinotan and Ojakorotu [3] describe the carnage caused by oil spill in the Niger Delta Region like this:

"It is estimated that in over 40 years of oil exploration and production in Nigeria, over 60,000 spills have been recorded, and over 2,000,000 barrels were discharged into the regions eco-system from oil spillages alone between 1976 and 1996. In 1997 and 1998, Shell Petroleum Development Company (SPDC) spilled 106,000 from its installations at Jones creek alone. In January1998, Mobil recorded its worst spillage at the Idoho offshore site which spread within 30 days from Akwa-Ibom to Lagos. Within the first months of 2008 alone, Nigeria recorded 418 cases of oil spills. disaster in Niger Delta Region."

All of these situations have created agitation and frustration in the communities that have been affected by the impact of oil spills in the region. The expectation is that Government and the oil companies will make attempt to pacify the people of the region, but that is not what their action seems to be doing. In its attempt, government, rather than demonstrate that it is trying to peacefully resolve the differences after the distrust and the suspicion that has been created through years of neglect and underdevelopment, its actions have rather portrayed it as authoritarian, high handed and employing the use of force to quell the legitimate concerns of those at the receiving end of the damage to their environment from what they seem not to fully benefit from. Afinotan and Ojakorotu [3] explain the actions of the oil company and Government in this manner:

"Through the provision of logistical and infrastructural support to the coercive arms of government, they clearly demonstrate that as far as the oil region is concerned, the infrastructure of oil and repression are closely linked, in such a way that power and repression flows simultaneously, from both the barrel of the gun and the barrel of crude oil."

The communities, on their part, have translated the repressive action of government as their region being treated as a "colonial enclave, whose resources they plunder with impunity."

\section{DISASTER PHENOMENON}

Disaster is a very complex phenomenon. Disaster has been a phenomenon of interest since as early as the twentieth century. Disaster research has evolved since the studies of Samuel Prince through the 1950s to 1970s where "interest centred on the behaviours of individuals and organizations and in the warning impact and immediate aftermath stages of disasters" [5].

Disaster has been defined in different ways by different researchers. Disasters have been described as "an event that combines destructive agents with a vulnerable population disrupting social needs for physical survival, social order and meaning" [6]. Several contemporary researchers have provided useful explanations that can help us catch a glimpse of what disasters are and how they can be created. Some of these works [5], [7][10] help us to understand the anatomy of disaster from various perspectives, for example political, economic, cultural, social and ecological. This knowledge and understanding is very important to help identify and develop mitigation and management. Disaster comes in different forms, shapes, and names, e.g. hurricanes, earthquakes, floods, oil spills, etc. Disasters have been described as devastating, erratic, extreme, hazardous, disruptive [11], 
politically controversial historical events [12], and catastrophic [13]. Disasters can be natural (hurricanes, earthquakes, flood, heat waves) and unnatural (oil spill, chemical plant accidents, bush fires and armed conflicts). Whatever label it is given, disasters (natural or unnatural), highlight the asymmetrical distribution of power and foreground the struggle of the state, corporations, and human agency for the redistribution of power [9].

An interesting perspective, one that is not readily visible, is that disaster is surrounded by a lot of uncertainties. Button [9] addresses this perspective in-depth. By saying "calamity is suffused with uncertainty" he brings an interesting perspective into the disaster discourse that "uncertainty does not simply exist - it is produced." Uncertainty produces stress in the lives of the communities that experiences the disaster. For example, the role of Government organs in disaster response and mitigation is implicated as one of the main sources of uncertainties during disaster response. Government is revealed as either downplaying community/public concerns by covering up facts or working with corporate organizations to create narratives that overwhelms public interest [9]. A closer look into the situation in the Niger Delta Region reveals these facts. Disaster, as an all-encompassing occurrence affects everyone in a community including children and women. Children and the young, especially those living in poverty, are at significant greater risk for negative outcomes during and following disasters.

Central to the whole concept and understanding of disaster is vulnerability, defined as "the degree of loss resulting from a potentially damaging phenomenon or insecurity of the well-being of individuals or communities in the face of a changing environment" [14]. Vulnerability has been described as "a concept linking people's relationship with their environment to the social forces, institutions and the cultural values that sustain and contest them" [15]. This points to the multidimensionality of disasters. The link between disaster, vulnerability and social forces is very important because even though seen as physical, disasters are also socially and culturally constructed occurrences. A disaster takes place when a destructive force intersects with a community in a socially configured pattern of vulnerability. Vulnerability arises from location, sociopolitical structure, production patterns, and ideology [5].

\subsection{Oil spill disaster in the Niger Delta Region}

Oil spills in the Niger Delta Region has been implicated as one of the major causes of environmental destruction which has directly and indirectly affected the social wellbeing of the people of the region in the last 58 years. The oil spills have not just been one-off events but in several locations in the Niger Delta have been recurring.

Oil spills data on the Niger Delta vary. The Niger Delta Human Development Report [1] reports that " 6,617 spills occurred between 1976 to 2001 with a loss of approximately three million barrels of oil." The report explains that $75 \%$ of this spill was not recovered, with approximately 6 percent is said to have spilled on land, 25 percent in swamps, and 69 percent was said to have spilled on offshore environment. These spills are reportedly caused "accidentally" and by "deliberate actions of local people" sabotaging pipelines in protest. Impact assessment reports "confirmed the death of floating and submerged aquatic vegetation, especially water lettuce. Dead crabs, fish and birds were also reported." The livelihoods sources of the people like fishing and farming have been seriously impacted and the people, not reimbursed, have been forced to go elsewhere to seek for other sources of livelihood. 
Without carrying out any empirical analysis the available literature on the extent of oil spills and the damage it has caused to the livelihoods and wellbeing of the people of the region, is enough to conclude that there is an oil spill disaster in the Niger Delta Region.

\subsection{Arms conflict disaster in Niger Delta Region}

Several works [1], [3], [16]-[18] have shown a strong correlation between the events that have taken place in the last six decades in the Niger Delta Region and the current spate of armed conflicts in the region. One of such events that is highly implicated is the activities of oil companies in the regions, the inattention of the Government to deal timely with the outfalls and its impact on the wellbeing of the communities in the region and the dashed hope and expectations of the communities.

Okpako [18] says conflict and violence in the region, branded as "youth restiveness" are directly "connected to the numerous unhealthy and detrimental environmental degradations rooted in the activities of the multi-national and local oil exploiters" and "the Federal Government's obnoxious and anti-host communities' policies, including the oppressive sharing formula of the huge wealth from oil." These have resulted in what has been described as "a hot bed of violence, insurgency, kidnapping, hostage-taking, oil pipeline sabotage, crude oil theft, gang wars, internecine struggles and so much else by way of anarchy and chaos" [3]. The situation has not always been like this, but has been created by some elements that I have referred to in this paper as "disaster causative agents."

What strikes me as I review literature on the armed conflict or militancy in the Niger Delta Region is the complexity and the multidimensionality of reasons given for the crisis. For example, Afinotan and Ojakorotu [3] see three dimensions wrapped up in the basic Niger Delta crisis. These are the Ijaw National struggle for self determination; The bands of "criminal cult gangs established, encouraged and funded by political godfathers dedicated to the theft of crude oil, kidnapping for ransom, assassination of political opponents, various gangs of brigandage and piracy in the creeks and upon the territorial seas"; and those who are said to be "genuinely concerned with the struggle for the actualization of a truly developed Niger Delta, free from poverty, degradation, unemployment, environmental pollution, economic and socio-political alienation, disease and squalor" [17], on the other hand see the triggers for crisis in Niger Delta as the "the revenue allocation formula and resource control, federalism, environmental degradation, state imposed poverty, unfulfilled promises made by the government to mention a few." In my opinion, all of these dimensions and the reasons proffered by these writers take their roots from the presence of oil in the region. The crisis or struggles and the catastrophe they have caused have resulted in wanton destructions of properties, loss of lives, stalled production of oil and increased poverty. The situation has recreated vulnerabilities among the poor community dwellers which will require them to develop different coping strategies which may be very difficult because of the complexity of the situation in which they now live in. Situations they are not familiar with. I examine closely the causative agents of these situations in the next section.

\section{DISASTER CAUSATION IN THE NIGER DELTA REGION}

The fact that all the happenings in the Niger Delta Region of Nigeria could culminate in disaster is obvious even to a non-disaster management professional. As far back as 2006 UNDP had alluded to the possibility of disaster by this statement: "The potential for a disaster arising from the Niger Delta and producing a conflagration across the country should not be underestimated" [1]. The disasters have come and we may be on the verge of snowball effect except if something drastic is done. 
Fig. 1 depicts the scenario in Niger Delta Region. This is just a diagrammatic summary of the realities on ground. The actual situation is deeper, more complex and multidimensional than can be expressed in the diagram.

The exploitation of oil resources in the Niger Delta began in 1956 with the discovery of oil in Oloibiri in Ogbia LGA of Bayelsa State. Before this period, the environment of the Niger Delta was said to be pristine. Community wellbeing and livelihood was heavily dependent on the waters for fishing business and on their lands for farming. Community organization social and cultural structures were as defined by the environment and traditions. The communities had vulnerabilities of course (climatic, under development and environmental), but it will appear they were coping within their vulnerabilities. Coping strategies at this time were mostly inherent based on local community knowledge and capabilities.

In 1956 when oil exploration and exploitation began, the communities were happy. They had high expectations and were looking forward to improved wellbeing. No one told them about the carnage to come, neither did they anticipate it. It is not clear from review of literature done whether any form of Environmental Impact Assessment (EIA) was carried out and if it was done, it is not clear how much, the possible impacts of Oil exploitation in a riverine area like the Niger Delta was discussed with the Niger Delta Communities. It is therefore not also clear whether the Niger Delta communities were prepared by the oil companies for what was to come ahead.

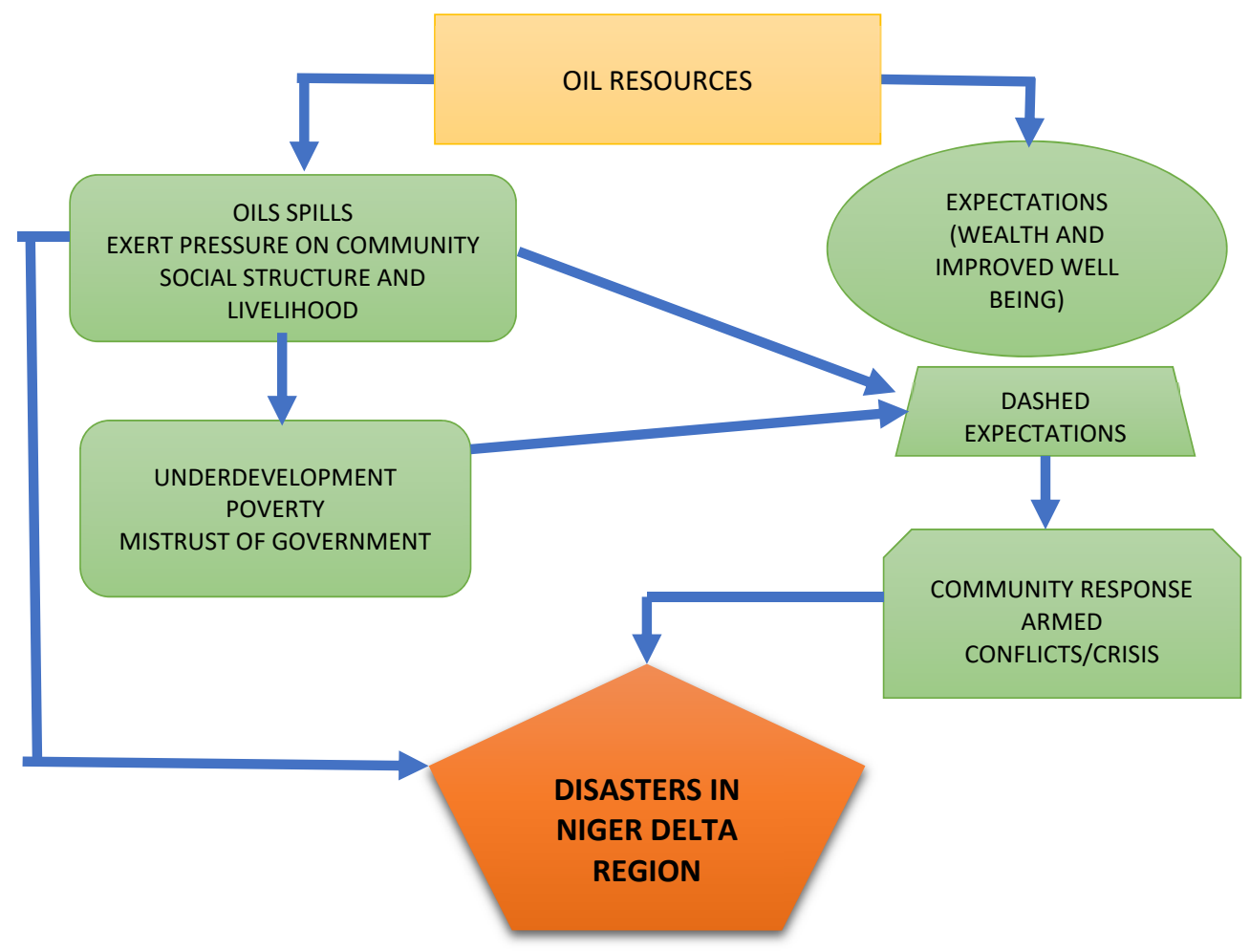

Figure 1: Diagrammatic expression of disaster causation in Niger Delta region. 
It will appear however that what should have been a blessing for the Niger Delta people became a "resource curse" as Okonofua [19] described it. Oil and gas wealth has become a curse in Nigeria due to the social, economic, and political instability as well as policy failures they engender [19]. According to Okonofua:

"The increase in oil wealth did not translate into improved standard of living for Nigerians, especially people of the Niger Delta. Instead, increases in poverty and inequality rates coincide with the discovery of oil and with increases in oil production and oil earnings."

Ereibi [2] confirms this saying; "And then one day, the people woke-up to the reality that rather than peace and joy, the black gold had brought sorrows and tears to their land. Their dreams died in their strides."

These failures to meet the expectation of the Niger Delta communities is what led to the conflicts. The failures of Government and the oil companies to meet the expectations of people, pressures from the degradation of the environment, loss of sources of livelihood (land resources and inability to fish in the creeks due to pollution) and the decimation of social and cultural structures of the people all led to uncertainties. In such pressured position the people responded. In my opinion, what we currently see as conflict is the communities' own way of responding. Is it the best response? Definitely not, but it is still a response all the same. Okonofua [19] referred to this response as a "new type of resistance movement in the Niger Delta." Signifying that there has been a different type of resistance before this one. That type of resistance is what the author referred to as "ideological struggle, aimed at both deconstructing and reconstructing mainstream ideas about the state, the delta's people and resources, and the logics of oil wealth appropriation and distribution."

Ken Saro-Wiwa, the Ogoni playwright and activist, led one of the ideological type resistance in the Niger Delta but he was charged for treason and executed by the Military leadership. This could probably be the reason for "this new type of resistance."

\subsection{Disaster causation analysis}

Two concepts/theories provide a basis for carrying out an analysis of the situation in the Niger Delta Region to further provide better understanding of the causative agents that acted individually or together to create the disasters in the region.

$\mathrm{Nel}$ and Righarts [20] apply three concepts around motive, incentive and opportunity to carry out strategic evaluations of why natural disasters give rise to violent civil conflicts. Even though this paper is not about natural disasters, I, however, find that these concepts can be equally applied to analysing the causes of armed conflict disaster in this paper.

\subsubsection{Motive}

$\mathrm{Nel}$ and Righarts [20] explain that motive helps to understand the evaluations of how and when a community that thinks it is not receiving its dues, brings the community to consider taking drastic action to alter its sources of discomfort. It is clear from documentation in literature that there has been widespread grievances and frustration among the Niger Delta people, brought about by what they see as deprivation by the Government of the day and the oil companies. This can be seen from their expectations of an improved wellbeing which never came. As explained by Nel and Righarts [20] "socio-economic grievances due to vertical (between individuals) and horizontal (between groups) income and wealth inequality" is a strong basis for grievances. This can be said to be present in the case of the 
Niger Delta people as explained earlier. This perceived inequality is responsible for the agitation for resource re-allocation which the people of the Niger Delta felt did not favour them. Efforts by activist through ideological struggles unfortunately did not yield desired results. These efforts were thwarted through military might and the politics within the country which became impediments to the people of the region. "Expectations of social mobility will be high in a society with a large cohort of young people and with a rapid rate of urbanization. If these expectations are thwarted by impediments to mobility related to social exclusion and/or ethnic discrimination, it is more likely that politically relevant grievances will arise" [20].

\subsubsection{Opportunity}

The Niger Delta communities could be said to have the conditions in which discontent can be organized, they have access to arms, they have very high numbers of restive youths and they are aggrieved. All of these reasons provide opportunity for agitation. The opportunity approach is possible in communities that have aggrieved people who think they are getting less than what they truly deserve. This depicts the Niger Delta people because these people have the conditions described above. It could explain why conflict has occurred.

\subsubsection{Incentives}

According to Nel and Righarts [20], having the opportunity to act alone may not be a strong motivator, however when it is combined with appreciation of what will be gained, it can provide incentive to act. This can be said to be true in the case of the conflicts in the Niger Delta Region. Kidnapping for ransom and the sabotaging of oil pipelines to syphon oil can bring gain to the agitators. This could be incentives enough for conflict.

\subsubsection{The frustration-aggression theory}

The frustration-aggression theory is the second theory/concept that may be used to explain the causes of armed conflict disaster. This revolves around the failure to meet a person or communities' value expectation. The frustration-aggression theory refers to the "gap between the value expectation and value capabilities. Or the lack of a need satisfaction defined as a gap between aspiration and achievement" [3]. Failure to address these gaps or disparities, as is the case of the failure of the Federal Government and the oil companies to resolve this in the Niger Delta, is responsible for agitations that have culminated in armed conflict disaster in the region.

From the foregoing discussions, the case of armed conflict disaster is clearly linked to grievances the Niger Delta people have as a result of unmet expectations. This disaster has already occurred and is currently playing out in the region. The failure of the Government and the oil companies to plan from the onset to ensure that the expectations of the communities from which the oil resources is extracted are met is implicated as the main causes of the disasters in the Niger Delta.

\section{CONCLUSION}

In this paper I examined, through the review of existing literature, the situation in the Niger Delta Region of Nigeria from the disaster perspective. The outcome of this review reveals that even though most of the literature have discussed the social and cultural situation in the region from various perspectives, not much attention has been given to looking at it from the angle of how the situations have caused multiple disasters, what the agents of this causation are and how they have interacted. 
This review shows that one disaster has contributed to the other. The oil spill that led to the deterioration of the environment and the destruction of the livelihood of the communities created an initial disaster, but failure to address this combined with other agents already discussed in this paper, created the current ongoing armed conflict disaster which has resulted in loss of lives, damage to properties and may have further increased the vulnerability of inhabitants of the region. It is clear from the review of the events in the region that the inability of the Government and that of the oil companies to calm the frustration of poor communities in the region has contributed to worsening the situation and allowing it to degenerate to the current militancy/armed conflicts. There is need for further studies that will help to understand how the multiple disasters in this region have affected the dynamics of vulnerability and the attendant resilient capacity of the communities in this region.

There is currently an amnesty in place in the Niger Delta Region and the Federal Government has decided to remediate the Ogoniland lands and water ways. If these can be achieved and sustained, there is hope that the anger of the Niger Delta people may be appeased and peace returned to the region once again. It is clear from the discussion in this paper that the dashed expectation of the Niger Delta people, an outcome from the in-attention of the authorities to the plight of the people has contributed to the present situation, Government efforts must be directed towards bringing hope to the Niger Delta people and restoring their confidence in the political system within the country in general and in the Niger Delta Region specifically. Top down resilience building support by the Government and the oil companies is necessary. This could be through emergency management and mitigation techniques that will address causes of the disaster. It will involve proper dialogue with the different groups that are currently aggrieved. The use of force should be discontinued as authoritarian approach will worsen rather than calm the situation.

\section{REFERENCES}

[1] UNDP, Niger Delta Human Development Report. United Nation Development Programme, Nigeria, 2006.

[2] Ereibi, A.G., Oil Exploitation and Challenges of Development in the Niger Delta Region, 2011.

[3] Afinotan, L.A. \& Ojakorotu, V., The Niger Delta Crisis: Issues, Challenges and Prospects. African Journal of Political Science and International Relations, 3(5), pp. 191-198, 2009.

[4] UNEP, Environmental Assessment of Ogoniland. United Nation Environmental Plan, 2011.

[5] Oliver-Smith \& Hoffman, S., The angry earth: disaster in anthropological perspective, Taylor and Francis, 1999.

[6] Rodriguez, H., Quarantelli, E.L. \& Dynes, R. R., Handbook of disaster research. Handbook of Sociology and Social Research, Springer, 2007.

[7] Bankoff, G., Frerks, G. \& Hilhorst, D., Mapping Vulnerability: Disasters, Development and People. Earthscan, 2004.

[8] Blaikie, P., Cannon, T., Davis, I. \& Wisner, B. At Risk: Natural Hazards, Peoples Vulnerability and Disasters, Taylor and Francis e-Library, 2005.

[9] Button, G., Disaster Culture: Knowledge and Uncertainty in Wake of Human and Environmental Catastrophe, Left Coast Press Inc., 2010.

[10] Klinenberg, E., Heat Wave: A Social Autopsy of Disaster in Chicago, (2), University of Chicago Press, 2015. 
[11] Colten, C.E., Hay, J. \& Giancarlo, A., Community Resilience and Oil Spills in Coastal Louisiana. Ecology and Society, 17(3), p. 5, 2012. http://dx.doi.org/ 10.5751/ES-05047-170305

[12] Vaughan, D., Theorizing disaster: Analogy, Historical Ethnography, and the Challenger Accident, SAGE Publications, 2004.

[13] Puleo, T.J. \& Sivak, H., Introduction: The Ambivalence of Catastrophe. American Geography Society of New York. The Geographical Review, 103(4), pp. 458-468, 2013. DOI: 10.1111/j.1931-0846.2013.00013.x.

[14] Oluoko-Odingo, A.A., Vulnerability and Adaptation to Food Insecurity and Poverty in Kenya. Annals of the Association of American Geographers, 101(1), pp. 1-20, 2011. http://dx.doi.org/10.1080/00045608.2010.532739.

[15] Oni, S.I. \& Okanlawon, K.R., Vulnerability and Environmental Security: Assessing the Impact of Disasters on a Community. Journal of Hum Ecol, 43(2), pp. 195 -201, 2013.

[16] Ifeka, C., ICTs 'Virtual Colonisation' \&Political Economy, Violence, Market Forces \& Militarisation in the Niger Delta. Review of African Political Economy, 31(99), pp. 144-150, ROAP Publication \& Taylor and Francis Ltd, 2004.

[17] Nwankwo, B.O., The Politics of Conflict over Oil in the Niger Delta Region of Nigeria: A Review of the Corporate Social Responsibility Strategies of the Oil Companies. American Journal of Educational Research, 3(4), pp. 383-392, 2015. DOI: 10.12691/education-3-4-1

[18] Okpako, J.E.F., Influence of Oil Activities on the Socio-Economic and Environmental Health of Host Niger Delta Communities in Nigeria. Mediterranean Journal of Social Science, 5(17), 2014. DOI: 10.5901/mjss.2014.v5n17p97.

[19] Okonofua, B.A., The Niger Delta Amnesty Program: The Challenges of Transitioning from Peace Settlements to Long-Term Peace, pp. 1-16, 2016. DOI: 10.1177/ 2158244016654522

[20] Nel, P. \& Righarts, M., Natural Disasters and the Risk of Violent Civil Conflict. International Studies Quarterly, 52, pp. 159-185, 2008. 